\title{
Effect of TM-Addition on the Aging Behaviour of Al-Mg-Si Alloys
}

\author{
Shumei Wang ${ }^{1}$, Kenji Matsuda ${ }^{2}$,* Tokimasa Kawabata ${ }^{2}$, \\ Yong Zou ${ }^{3}$, Toshinari Yamazaki ${ }^{2}$ and Susumu Ikeno ${ }^{2}$ \\ ${ }^{1}$ Graduate School of Science and Engineering for Education, University of Toyama, Toyama 930-8555, Japan \\ ${ }^{2}$ Graduate School of Science and Engineering for Research, University of Toyama, Toyama 930-8555, Japan \\ ${ }^{3}$ Graduate School of Science and Engineering for Research, Shandong University, Jinan, Shandong, P. R. China
}

\begin{abstract}
Microstructure and aging hardness variation of Al-Mg-Si-TM alloys ( $\mathrm{TM}=\mathrm{Mn}, \mathrm{Cr}, \mathrm{Fe}, \mathrm{Y}$, and $\mathrm{Gd}$ ) were investigated to reveal the effect of TMs on the age-hardening behavior of Al-Mg-Si-TM alloys. The peak hardness of Cr- and Fe-added alloys is similar to the base alloy, while the peak hardness of Mn-, Gd-, and Y-added alloys is much lower than the base alloy. It was found different TMs formed the dispersoids with different ratio of TM/Si calculated from the EDS result of the dispersoid. The Si expensed for the formation of the dispersoid is the most for Yadded alloy and the least for Fe-added alloy among the five TM-added alloys. It is thought that this will result in the difference of Si in the matrix for the formation of the precipitate. [doi:10.2320/matertrans.M2010370]
\end{abstract}

(Received October 22, 2010; Accepted November 18, 2010; Published January 13, 2011)

Keywords: aluminum-magnesium-silicon alloys, transition metals, age-hardening, precipitation, transmission electron microscopy

\section{Introduction}

Transition metals (TMs), such as $\mathrm{Cr}$, Fe and $\mathrm{Mn}$, are usually added to Al-Mg-Si alloys for grain refinement. But these transition elements will easily form some dispersoids as $\mathrm{Al}(\mathrm{TM}) \mathrm{Si}$. According to Terai and Baba, ${ }^{1)} \mathrm{Cr}$ and $\mathrm{Mn}$ affect to the electrical conductivity of Al-Mg-Si alloy for extruded, annealed and even aged samples. It seems that $\mathrm{Cr}$ and $\mathrm{Mn}$ are more stable to remain in the matrix as solute elements than other elements, in addition to make insoluble intermetallic compounds as Al-Si-TMs. The effect of $\mathrm{Cr}$ and $\mathrm{Fe}$ addition on the age-hardening behavior of 6000 series alloys is reported by Matsuda et al. ${ }^{2)}$ They indicated that the addition of $(\mathrm{Cr}+\mathrm{Fe})$ decreased peak hardness. And $(\mathrm{Cr}+\mathrm{Fe})$-bearing alloys included $\mathrm{AlSi}(\mathrm{CrFe})$ and $\mathrm{AlSiFe}$ dispersoids, which had depleted zones around them, and the number density of precipitates decreased in those alloys. Laughlin et al. ${ }^{3)}$ reported an investigation of the effect of Mn content on the aging kinetics of $\mathrm{Al}$ alloys based on the 6022 composition and got the conclusion that the Mn level had very little effect on the peak hardness which developed in the 6022 variants. TMs, such as $\mathrm{Y}$ and $\mathrm{Gd}$, has been reported to form the dispersoid as $\mathrm{Al}(\mathrm{TM}) \mathrm{Si}^{4-8)}$ in $\mathrm{Al}$ alloy, which is similar to $\mathrm{Cr}, \mathrm{Mn}$ or Fe. It is thought that the addition of $\mathrm{Y}$ or $\mathrm{Gd}$ in $\mathrm{Al}-\mathrm{Mg}-\mathrm{Si}$ alloy will cause a similar result to the effect of $\mathrm{Cr}$, $\mathrm{Mn}$ or Fe on the precipitation.

The aim of this work is to focus on the following issues: (1) the variation of aging hardness for the alloys with different TMs addition, (2) the difference of the dispersoids formed with TMs addition, and (3) the effect of TMs on the microstructure of the alloys. With this purpose in mind, hardness test and transmission electron microscopy (TEM) are used to determine these properties of Al-Mg-Si alloys with different transition metals addition.

\section{Experimental}

The quasi-binary alloy of $\mathrm{Al}-1.06 \mathrm{Mg}_{2} \mathrm{Si}$ (at\%) is usually

*Corresponding author, E-mail: matsuda@eng.u-toyama.ac.jp called as the base alloy for Al-Mg-Si ternary alloy. In this work, the TM-added alloys (at\%) of Al-1.06 $\mathrm{Mg}_{2} \mathrm{Si}-0.2 \mathrm{TM}$ (TM-added alloy, $\mathrm{TM}=\mathrm{Mn}, \mathrm{Cr}, \mathrm{Fe}, \mathrm{Y}$, and $\mathrm{Gd}$ ) were prepared by laboratory casting. They were melting in air using $99.99 \%$ pure $\mathrm{Al}, 99.9 \%$ pure $\mathrm{Mg}, 99.9 \%$ pure $\mathrm{Si}$, and $99.9 \%$ pure TMs. The composition analysis of the obtained alloy is given in Table 1. The samples for Vickers hardness and TEM observation were solution heat treated at $848 \mathrm{~K}$ for $3.6 \mathrm{ks}$ in a circulating air furnace, cold water quenched, and followed by the artificial aging treatments at $473 \mathrm{~K}$ for different periods of time. The samples for DSC test were solution heat treated at $823 \mathrm{~K}$ and quenched into cold water.

Vickers hardness was measured using Akashi MVK-EII hardness tester (load: $0.98 \mathrm{~N}$, holding time: $15 \mathrm{~s}$ ). The hardness values reported here represent the average of at least ten measurements. TEM observation was performed using Topcon EM-002B equipped with an energy dispersive $\mathrm{X}$-ray spectroscopy (EDS). The accelerating voltage was $120 \mathrm{kV}$.

\section{Results and Discussion}

Figure 1 shows the optical micrographs of the alloys with different TMs added. The grain size is calculated as 649, 64, $40,91,47$ and $55 \mu \mathrm{m}$ for different alloys, as shown in Table 1. The grain size of TM-added alloys is much smaller than those of the base alloy, which is resulted from the grain refinement effect of TM addition. Figure 2 shows the variation of the micro vickers hardness for the alloys aged at $473 \mathrm{~K}$, which is plotted as a function of aging time. The as-quenched hardness of the TM-added alloys is higher than the base alloy because of the smaller grains formed in TMadded alloys. The peak hardness of $\mathrm{Cr}$ - or Fe-added alloy is similar to the base alloy. The peak hardness of Mn, Y-, and Gd-added alloys, however, is much lower than the base alloy. This result is supported by our previous work ${ }^{2)}$ but different with Laughlin et $a l .{ }^{3)}$ The reason for the difference with Laughlin et al. is properly caused by the difference of the chemical composition between the alloys used in this work 
Table 1 Composition analysis result of the alloys used in this work (at\%).

\begin{tabular}{|c|c|c|c|c|c|c|c|c|c|c|c|}
\hline Alloys & $\mathrm{Mg}$ & $\mathrm{Si}$ & $\mathrm{Fe}$ & $\mathrm{Cu}$ & $\mathrm{Mn}$ & $\mathrm{Cr}$ & $\mathrm{Zn}$ & $\mathrm{Y}$ & $\mathrm{Gd}$ & $\mathrm{Al}$ & $\begin{array}{l}\text { Grain size } \\
\quad(\mu \mathrm{m})\end{array}$ \\
\hline Base alloy & 0.71 & 0.37 & $<0.01$ & $<0.01$ & $<0.01$ & 0.00 & $<0.01$ & 0.00 & 0.00 & bal. & 649 \\
\hline Fe-addition alloy & 0.67 & 0.32 & 0.16 & $<0.01$ & $<0.01$ & 0.00 & $<0.01$ & 0.00 & 0.00 & bal. & 91 \\
\hline Mn-addition alloy & 0.75 & 0.31 & $<0.01$ & $<0.01$ & 0.24 & $<0.01$ & $<0.01$ & 0.00 & 0.00 & bal. & 40 \\
\hline Gd-addition alloy & 0.73 & 0.35 & 0.02 & $<0.01$ & $<0.00$ & 0.00 & $<0.01$ & 0.00 & 0.19 & bal. & 55 \\
\hline
\end{tabular}
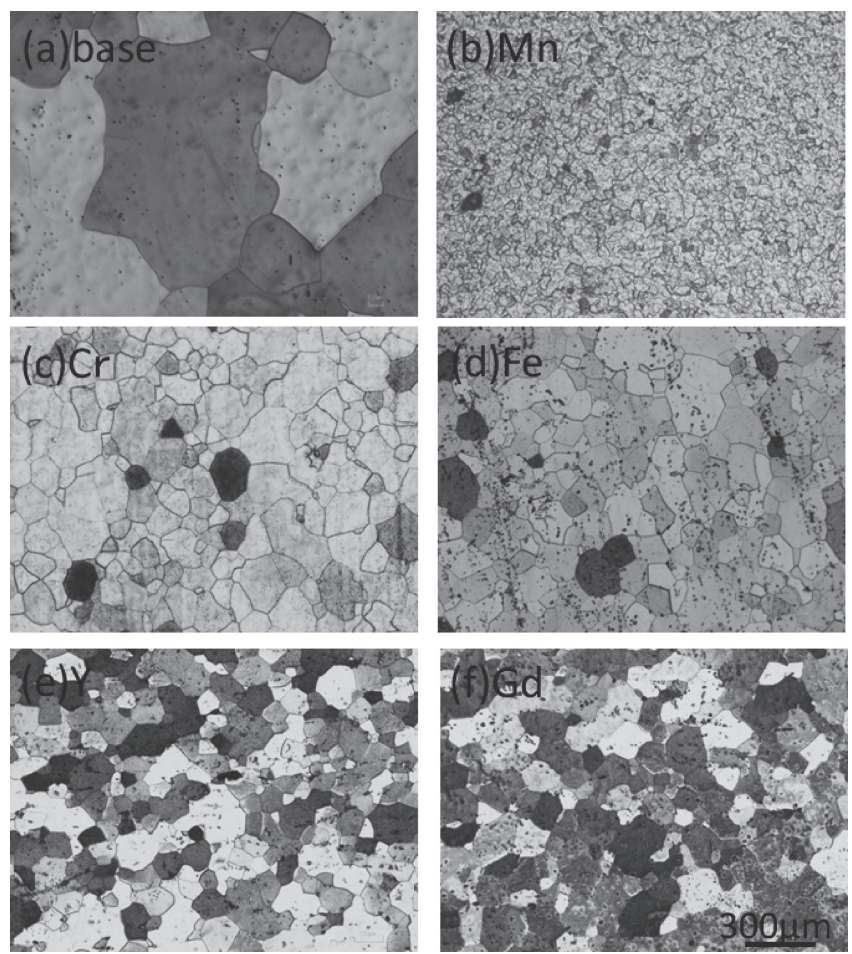

Fig. 1 Optical micrographs of the alloys with different TMs addition: (a) base, (b) Mn-, (c) Cr-, (d) Fe-, (e) Y-, and (f) Gd-added alloys.

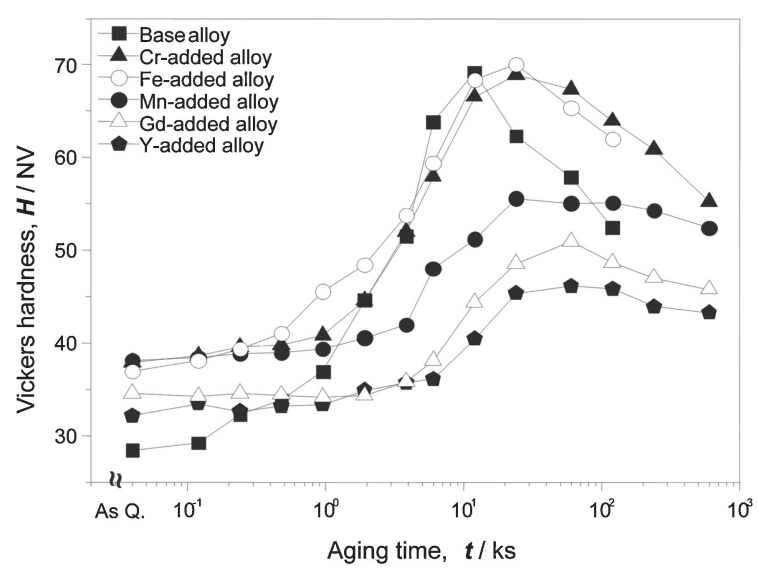

Fig. 2 Micro Vickers hardness curves of six alloys aged at $473 \mathrm{~K}$.

and the previous work, ${ }^{3)}$ in which the existence of 1.0 mass $\%$ ex.Si for the alloy including $\mathrm{Cu}$ is enough to form the precipitates that affect the age hardening behavior of the alloy.
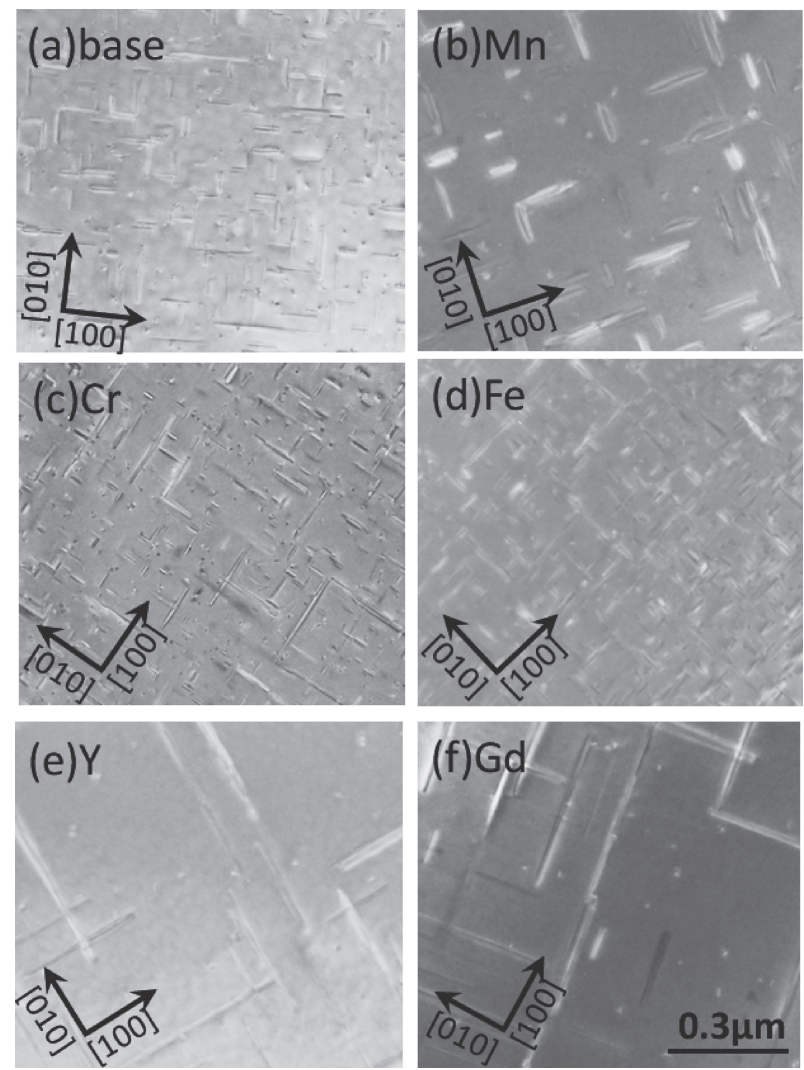

Fig. 3 TEM bright-field images of the alloys with different TMs addition: (a) base, (b) Mn-, (c) Cr-, (d) Fe-, (e) Y-, and (f) Gd-added alloys.

The six alloys peak-aged at $473 \mathrm{~K}$ are taken to examine the difference of the precipitation distribution in this work. The TEM bright-field images are shown in Fig. 3. There are only needle-shaped precipitates aligning with $\langle 100\rangle_{\mathrm{Al}}$ direction for the six alloys. The number density of these precipitates can be calculated as $146,157,150,37,36$ and $31 \mu^{-2}$ for the base, Fe-, Cr-, Mn-, Y-, and Gd added alloys, respectively. The number density of the precipitates for Mn, Y-, and Gdadded alloys is much lower than the other alloys, which is attributed to one of the reason why their peak hardness is much lower than the other alloys. The difference between the peak hardness and the as-quenched hardness is described as $\Delta H V$. The variation of $\Delta H V$ according to the number density of the precipitates $(\mathrm{N})$ is shown in Fig. 4(a). The square root of number density of the precipitates, $\mathrm{N}^{1 / 2}$, for every alloy was calculated and it was normalized to divide the value $\mathrm{N}^{1 / 2}$ of Fe-added alloy, as $\mathrm{L}^{-1}$, which is assumed as the inverse of 

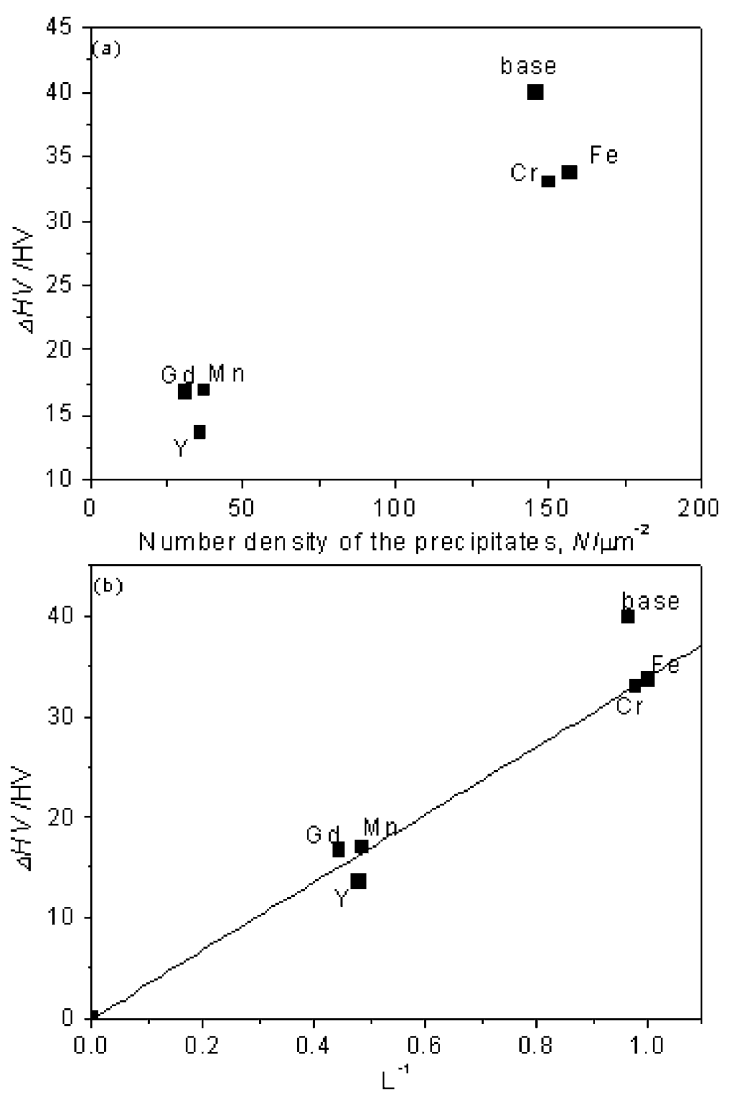

Fig. 4 Variation of $\Delta H V$ according to (a) the number density and (b) $\mathrm{L}^{-1}$.

the normalized distance between precipitates. The variation of $\triangle H V$ against $\mathrm{L}^{-1}$ is shown in Fig. 4(b). There is a linear relationship between two parameters, which is thought as the mechanism for the effect of the precipitates on the motion of dislocation, $\tau \propto \mathrm{L}^{-1}$, where $\tau$ is the applied stress and $\mathrm{L}$ is the average distance between the particles. ${ }^{9)}$

HRTEM observation is taken for Fe-, Mn-, Gd-, and Y-added alloys peak-aged at $473 \mathrm{~K}$. Figure 5 shows the HRTEM images of the typical precipitates observed in Feadded alloy as an example. Figure 5(a) shows the precipitate with the parallelogram networks of the bright dots. Its interior angle $(\theta)$ is not fixed to a certain degree but spans the range of $60^{\circ}<\theta<90^{\circ}$. It can be attributed to the parallelogram-type precipitate, ${ }^{10)}$ which is the transition phase between GP-zone and the $\beta^{\prime}$ phase. Figure 5(b) also shows the precipitate with the parallelogram networks of the bright dots. And its interior angle is fixed to $75^{\circ}$. This can be attributed to the $\beta^{\prime \prime}$ phase, ${ }^{11)}$ which is a special case of the parallelogram-type precipitate. The hexagonal networks of the bright dots of the precipitate in Mn-added alloy are observed in Fig. 5(c) with the spacing about $0.7 \mathrm{~nm}$, and the direction of the precipitate (indicated as $\mathrm{P}$ ) is inclined by $10^{\circ}$ to the $\langle 100\rangle_{\mathrm{Al}}$ direction of the matrix which is similar to the data shown in Refs. 12, 13) for the $\beta^{\prime}$ phase. The randomtype precipitate, ${ }^{14)}$ which is the predominant precipitate at the early aging stage and a precursor of the parallelogramtype precipitate appearing after GP-zone, cannot be observed as the main precipitate in this alloy. The precipitate distribution of the alloys is shown in Fig. 6 with the decreasing order of the peak hardness from the top to the
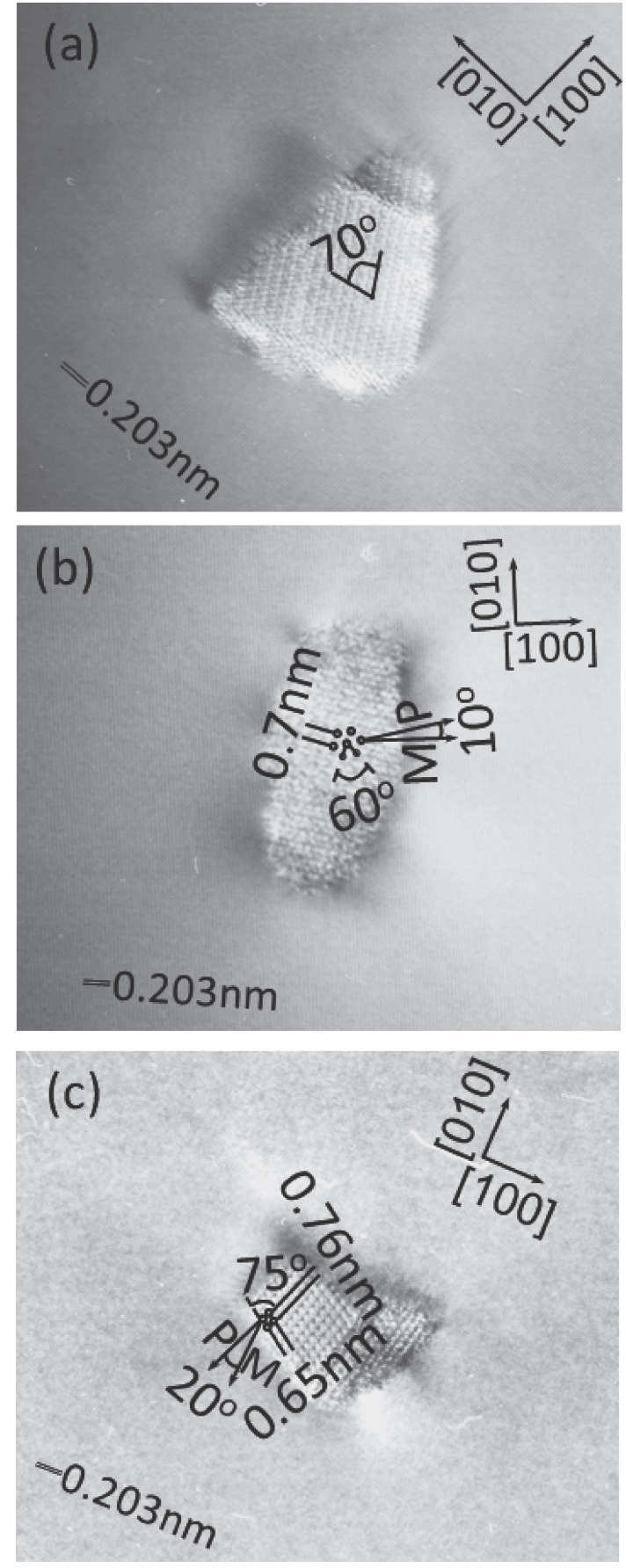

Fig. 5 HRTEM images of the precipitates formed in Fe-added alloy peakaged at $473 \mathrm{~K}$.

bottom. The distribution of the precipitates for the base alloy has been reported in our previous work. ${ }^{10)}$ The random-type and parallelogram-type precipitates are observed as the main precipitates in the base alloy. The precipitation sequence for four TM-added alloys is shifted to more stable phases than the base alloy because the random-type precipitates are formed between GP zone and parallelogram-type precipitate, $\beta^{\prime \prime}$ or $\beta^{\prime}$ phase according to our previous report. ${ }^{15)}$

It has been well known that $\mathrm{Mn}, \mathrm{Cr}$ or $\mathrm{Fe}$ will form the dispersoids of $\mathrm{Al}(\mathrm{TM}) \mathrm{Si}$ with the inhomogeneous distribution. The dispersoids are observed in five TM-added alloys in this work, as shown in Fig. 7(a), which is taken 
from Cr-added alloy as an example. The size of the dispersoid is much larger than the precipitates. And there is a precipitate free zone around the dispersoid. Figure 7(b)(f) show the EDS spectrum of the dispersoids formed in different TM-added alloys. Al, Si, and TMs (Mn, Cr, Fe, Gd, and $\mathrm{Y}$ ) peaks were detected for all TM-added alloys. The

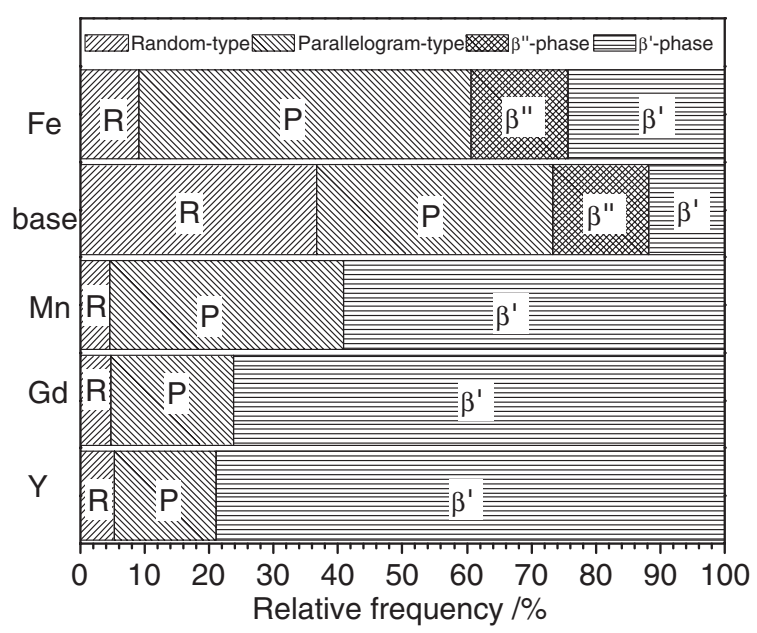

Fig. 6 Relative frequency of the precipitates in the five alloys. relative ratio of TM:Si is determined using the Cliff-Lorimer method shown in Fig. 8 with respect to $\mathrm{Al}$ (i.e. matrix). ${ }^{16)}$ The TM:Si ratio is estimated as 2.1, 1.7, 1.5, 1.3 and 0.5 for the dispersoids formed in $\mathrm{Fe}-, \mathrm{Cr}-, \mathrm{Mn}-, \mathrm{Gd}-$, and $\mathrm{Y}$-added alloys, respectively. The dispersoids with the TMs used in this work are reported before, as shown in Table 2. The dispersoids observed in TM-added alloys are thought to attribute to $\mathrm{Al}_{8} \mathrm{Fe}_{2} \mathrm{Si}^{24,25)} \mathrm{Al}_{8.9} \mathrm{Cr}_{4} \mathrm{Si}_{2.1},{ }^{29)} \mathrm{Al}_{12} \mathrm{Mn}_{3} \mathrm{Si}_{2}{ }^{34,35)}$ $\left.\left(\mathrm{Al}_{15} \mathrm{Mn}_{3} \mathrm{Si}_{2}{ }^{36)}\right), \mathrm{AlGd}_{4} \mathrm{Si}_{3},{ }^{7}\right)$ and $\mathrm{Al}_{2} \mathrm{YSi}_{2}{ }^{8)}$ for $\mathrm{Fe}-, \mathrm{Cr}-$, $\mathrm{Mn}-, \mathrm{Gd}-$, and Y-added alloys, respectively. Amount of $\mathrm{Si}$ for the formation of homogeneous precipitates becomes small and the formation of the precipitates will decrease in TM-added alloy because of the existence of the dispersoids formed with $\mathrm{Si}$. As the interface between the dispersoid and the matrix acts as the sink of the quenched-in vacancy, vacancy in the matrix decreases and it causes the decrease of the diffusion rate of the solute atom in the matrix and the number density of nucleation sites as vacancy-solute atom. On the other hand, $\beta^{\prime}$ phase is observed as the main precipitate in Mn-, Y-, and Gd-added alloys in which much $\mathrm{Si}$ is expensed to form the dispersoid. The absence of supersaturation of solute atoms for the nucleation furthermore results in the decrease of the precipitates in TM-added alloy. The relationship between the peak hardness and the

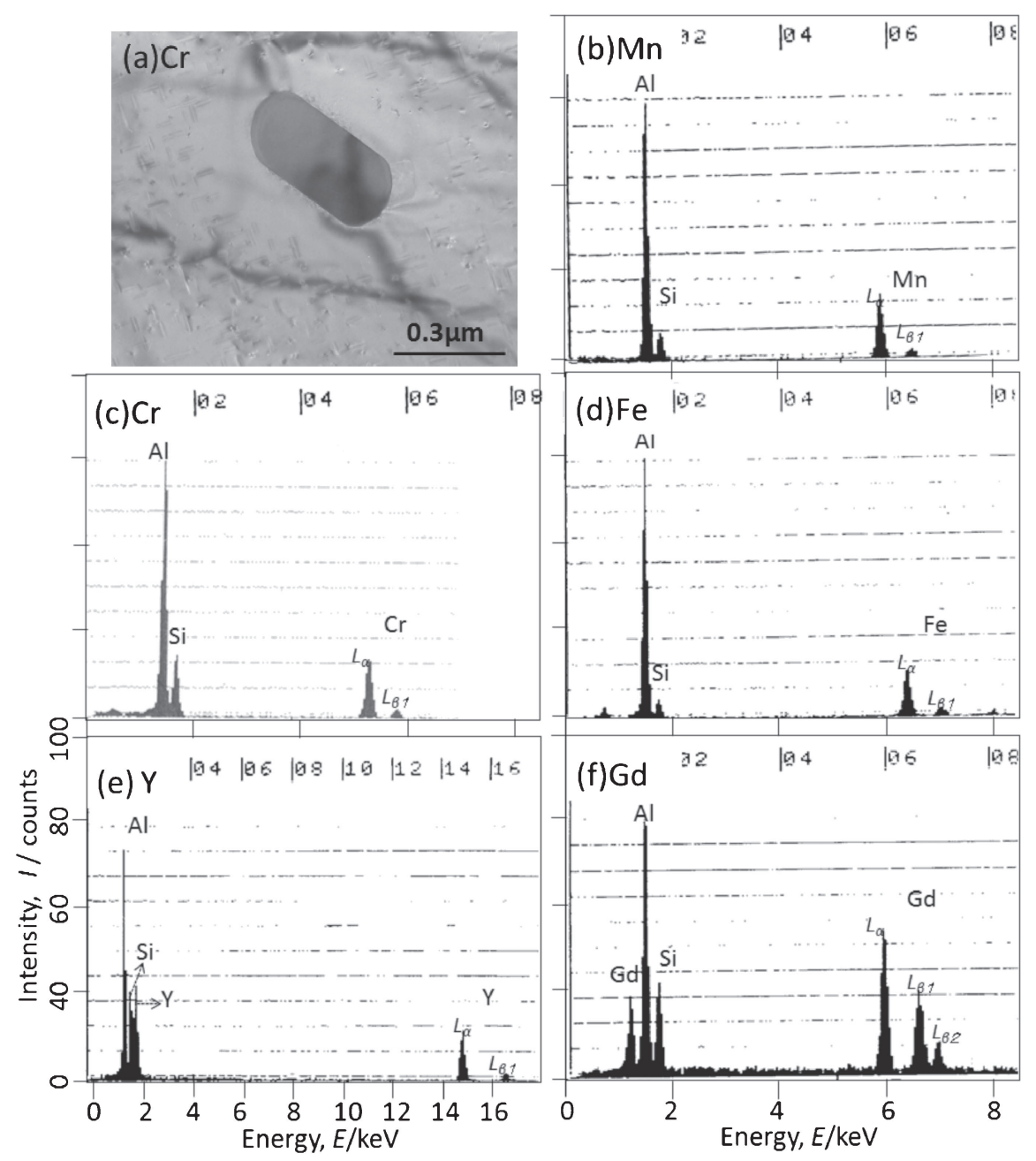

Fig. 7 (a) TEM image of the dispersoid formed in Cr-added alloy, (b)-(e) EDS spectrum of the disperoids formed in different TM-added alloys. 


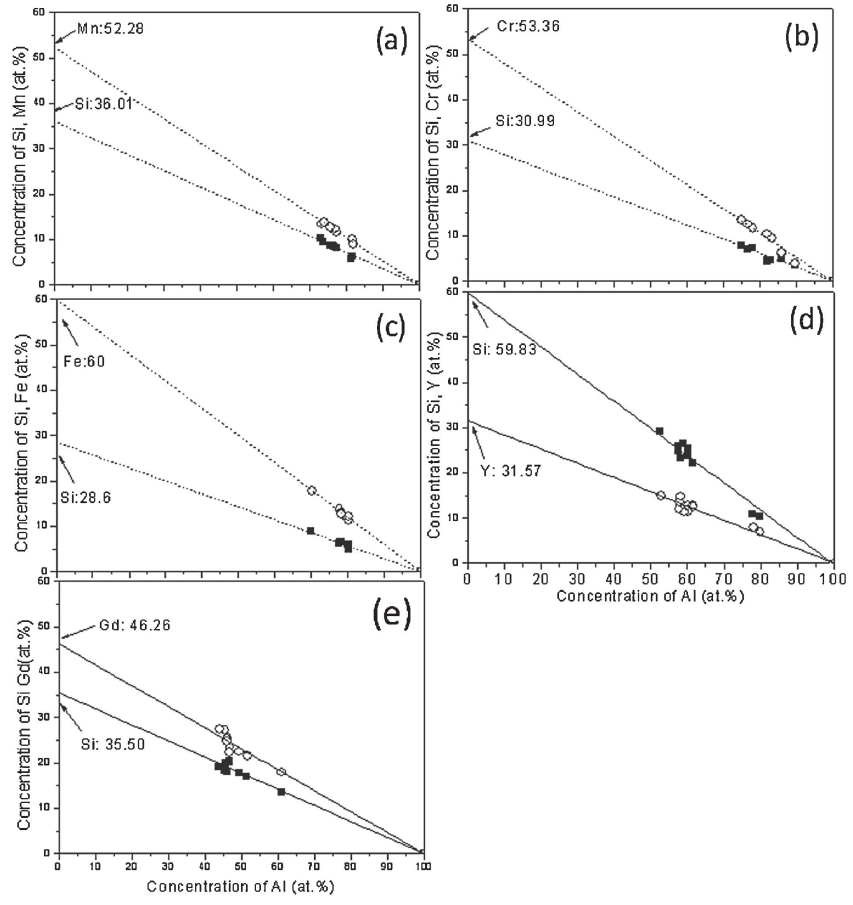

Fig. 8 Determination of the relative ratio of $\mathrm{TM} / \mathrm{Si}$ for the dispersoids obtained in (a) Mn-, (b) Cr- and (c) Fe-, (d) Y-, and (e) Gd-added alloys using Cliff-Lorimer method.

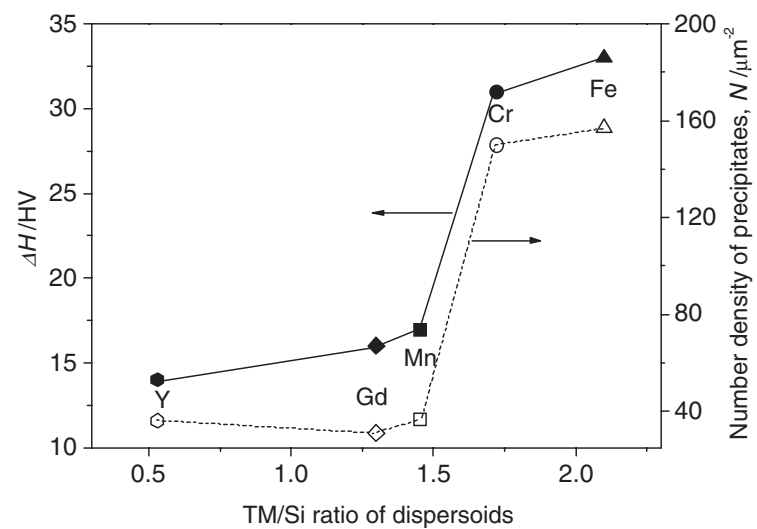

Fig. 9 Relationship of TM/Si ratio, peak hardness and number density of the precipitates.

$\mathrm{TM} / \mathrm{Si}$ ratio, as well as the number density of the precipitates and the TM/Si ratio is shown in Fig. 9. It can be seen that the lower the $\mathrm{TM} / \mathrm{Si}$ ratio is, the lower the number density of the precipitates is, and the lower the peak hardness is.

The bond overlap population (BOP) value by discretevariational $(D V)-X a$ method using the BONDODR program $^{37)}$ was calculated for the cluster indicated in Fig. 10 which include some TM elements and summarized Fig. 11 as the relationship with the ratio of $\mathrm{TM} / \mathrm{Si}$ in the dispersoid reported before. It is the easiest to form the dispersoid of AlYSi because the value of BOP is the highest for Y-added alloy. On the other hand, the value of BOP calculated in this work is larger than $\mathrm{A}-\mathrm{Mg}-\mathrm{Si}-\mathrm{Co}$ or $\mathrm{Al}-\mathrm{Mg}-\mathrm{Si}-\mathrm{Ni}$ alloy with BOP about 0.3 , in which the dispersoid $\mathrm{Al}(\mathrm{TM})$ is formed without Si.
Table 2 Dispersoids in Al alloys reported before.

\begin{tabular}{|c|c|c|c|c|}
\hline TM & Dispersoid & Crystal Structure & Alloy (mass\%) & Ref. \\
\hline \multirow{9}{*}{$\mathrm{Fe}$} & $\mathrm{Al}_{2} \mathrm{FeSi}$ & orthorhombic & $\mathrm{Al}-\mathrm{Si}$ & 17) \\
\hline & $\mathrm{Al}_{3} \mathrm{FeSi}_{2}$ & hexagonal & $\mathrm{Al}-\mathrm{Si}$ & 18) \\
\hline & $\mathrm{Al}_{4} \mathrm{Fe}_{2} \mathrm{Si}$ & hexagonal & $\mathrm{Al}-\mathrm{Si}$ & 19) \\
\hline & $\mathrm{Al}_{7} \mathrm{Fe}_{2} \mathrm{Si}$ & hexagonal & $\mathrm{Al}-\mathrm{Si}$ & 20) \\
\hline & $\mathrm{Al}_{12} \mathrm{Fe}_{75} \mathrm{Si}_{13}$ & cubic & $\mathrm{Al}-\mathrm{Si}$ & 21) \\
\hline & $\mathrm{Al}_{5} \mathrm{FeSi}$ & monoclinic & $\begin{array}{l}\text { Al-0.54Mg-0.28Si-0.24Fe- } \\
0.014 \mathrm{Mn}-0.005 \mathrm{Cu}-0.009 \mathrm{Ti}\end{array}$ & 22) \\
\hline & $\mathrm{Al}_{4} \mathrm{FeSi}_{2}$ & tetragonal & $\mathrm{Al}-25 \mathrm{Si}-5 \mathrm{Fe}-3 \mathrm{Cu}$ & 23) \\
\hline & $\mathrm{Al}_{8} \mathrm{Fe}_{2} \mathrm{Si}$ & cubic & $\begin{array}{l}\text { Al-0.58Mg-0.58Si-0.29Fe- } \\
0.003 \mathrm{Mn}-0.007 \mathrm{Ti}-0.004 \mathrm{~B}- \\
0.002 \mathrm{Cu}-0.004 \mathrm{~Pb}-0.006 \mathrm{Zn}\end{array}$ & 24) \\
\hline & $\mathrm{Al}_{8} \mathrm{Fe}_{2} \mathrm{Si}$ & hexagonal & 一 & 25) \\
\hline \multirow{6}{*}{$\mathrm{Cr}$} & $\mathrm{AlCr}_{6} \mathrm{Si}$ & cubic & $\mathrm{Al}-\mathrm{Si}$ & 26) \\
\hline & $\mathrm{Al}_{10} \mathrm{Cr}_{22} \mathrm{Si}$ & teragonal & Al-Si & 27) \\
\hline & $\mathrm{Al}_{13} \mathrm{Cr}_{4} \mathrm{Si}_{4}$ & cubic & Al-Si & 28) \\
\hline & $\mathrm{Al}_{9} \mathrm{Cr}_{63} \mathrm{Si}_{28}$ & teragonal & $\mathrm{Al}-\mathrm{Si}$ & 26) \\
\hline & $\mathrm{Al}_{14} \mathrm{Cr}_{32} \mathrm{Si}_{54}$ & hexagonal & $\mathrm{Al}-\mathrm{Si}$ & 26) \\
\hline & $\mathrm{Al}_{8.9} \mathrm{Cr}_{4} \mathrm{Si}_{2.1}$ & hexagonal & Al-24Cr-10Si & 29) \\
\hline \multirow{10}{*}{$\mathrm{Mn}$} & $\mathrm{Al}_{3} \mathrm{Mn}_{3} \mathrm{Si}_{4}$ & hexagonal & $\mathrm{Al}-\mathrm{Si}$ & $30)$ \\
\hline & $\mathrm{Al}_{3} \mathrm{Mn}_{4} \mathrm{Si}_{2}$ & cubic & $\mathrm{Al}-\mathrm{Si}$ & 31) \\
\hline & $\mathrm{Al}_{5} \mathrm{Mn}_{2} \mathrm{Si}_{5}$ & hexagonal & $\mathrm{Al}-\mathrm{Si}$ & 18) \\
\hline & $\mathrm{Al}_{9} \mathrm{Mn}_{2} \mathrm{Si}$ & cubic & $\mathrm{Al}-\mathrm{Si}$ & 32) \\
\hline & $\mathrm{Al}_{9} \mathrm{Mn}_{3} \mathrm{Si}$ & hexagonal & Al-Si & $30)$ \\
\hline & $\mathrm{Al}_{9} \mathrm{Mn}_{4} \mathrm{Si}_{3}$ & hexagonal & $\mathrm{Al}-\mathrm{Si}$ & 31) \\
\hline & $\mathrm{Al}_{13} \mathrm{Mn}_{10} \mathrm{Si}_{7}$ & monoclinic & $\mathrm{Al}-\mathrm{Si}$ & 33) \\
\hline & $\mathrm{Al}_{12} \mathrm{Mn}_{3} \mathrm{Si}_{2}$ & cubic & $\begin{array}{l}\text { Al-0.87Si-1.17Si-0.37Mn- } \\
0.29 \mathrm{Cr}\end{array}$ & 34) \\
\hline & $\mathrm{Al}_{12} \mathrm{Mn}_{3} \mathrm{Si}_{2}$ & cubic & Al-0.91Mg-1.11Si-0.4Mn & $35)$ \\
\hline & $\mathrm{Al}_{15} \mathrm{Mn}_{3} \mathrm{Si}_{2}$ & cubic & $\begin{array}{l}\text { Al-(0.3-0.45)Mg-0.35Mn- } \\
(6.5-7.5) \mathrm{Si}-0.6 \mathrm{Fe}-0.25 \mathrm{Ti}\end{array}$ & 36) \\
\hline \multirow{5}{*}{$\mathrm{Gd}$} & $\mathrm{AlGdSi}$ & hexagonal & $\mathrm{Al}-\mathrm{Si}$ & 4) \\
\hline & $\mathrm{Al}_{2} \mathrm{GdSi}_{2}$ & hexagonal & $\mathrm{Al}-\mathrm{Si}$ & 5) \\
\hline & $\mathrm{Al}_{3} \mathrm{Gd}_{6} \mathrm{Si}$ & hexagonal & $\mathrm{Al}-\mathrm{Si}$ & 6) \\
\hline & $\mathrm{Al}_{58} \mathrm{Gd}_{33} \mathrm{Si}_{9}$ & cubic & $\mathrm{Al}-\mathrm{Si}$ & 4) \\
\hline & $\mathrm{AlGd}_{4} \mathrm{~S}_{3}$ & orthorhomic & $\mathrm{Al}-\mathrm{Si}$ & 7) \\
\hline \multirow{3}{*}{ Y } & $\mathrm{Al}_{3} \mathrm{Y}_{6} \mathrm{Si}$ & hexagonal & $\mathrm{Al}-\mathrm{Si}$ & 6) \\
\hline & $\mathrm{Al}_{14} \mathrm{Y}_{5} \mathrm{Si}$ & hexagonal & $\mathrm{Al}-\mathrm{Si}$ & 8) \\
\hline & $\mathrm{Al}_{2} \mathrm{YSi}_{2}$ & cubic & $\mathrm{Al}-\mathrm{Si}$ & 8) \\
\hline
\end{tabular}

\section{Conclusions}

The grain refinement effect of TMs causes the grain size of the TM-added alloys smaller than the base alloy, which results in the increase of the hardness for as-quenched TMadded alloys.

The precipitates in four alloys peak-aged at $473 \mathrm{~K}$ are observed by HRTEM and classified as the random-type precipitate, parallelogram-type precipitate, $\beta^{\prime \prime}$ phase and $\beta^{\prime}$ phase. The precipitation sequence for TM-added alloys is shifted to more stable phases, parallelogram-type precipitate, 


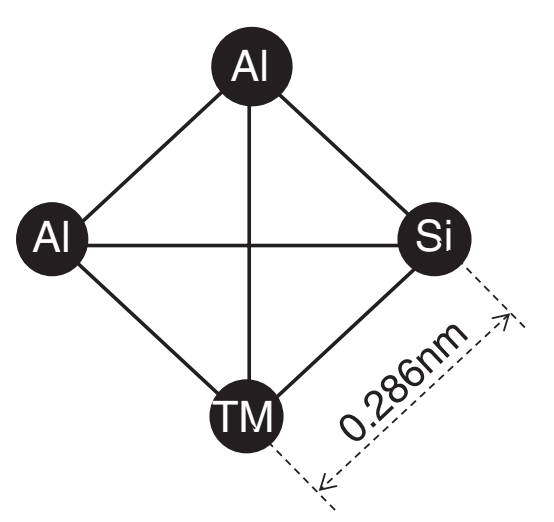

Fig. 10 Cluster model for the calculation of BOP.

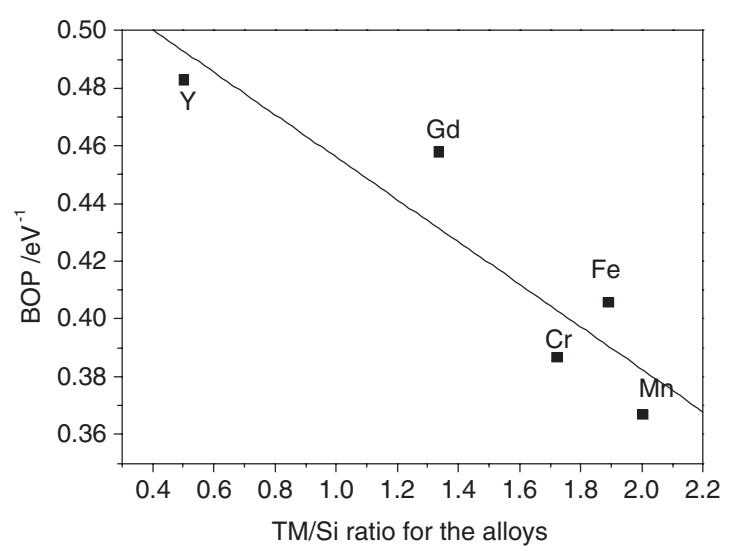

Fig. 11 Variation of BOP according to ratio of TM/Si for the alloys.

$\beta^{\prime \prime}$ phase and $\beta^{\prime}$ phase, than the base alloy in which the random-type precipitate is observed as the main precipitate.

The dispersoids of $\mathrm{Al}(\mathrm{TM}) \mathrm{Si}$ are formed in TM-added alloys. The ratio of TM/Si calculated from the EDS result of the dispersoid is the highest for Fe-added alloy and lowest for Y-added alloy. The peak hardness of Fe- and Co-added alloys is similar to the base, while the Mn-, Gd-, and Y-added alloys much lower than the base alloy.

It is the easiest to form the dispersoid with $\mathrm{Si}$ in $\mathrm{Y}$-added alloy according to its highest value of BOP. The BOP result obtained in this work indicates that $\mathrm{Al}(\mathrm{TM}) \mathrm{Si}$ dispersoid is formed easier in $\mathrm{Cr}-, \mathrm{Mn}-$, $\mathrm{Fe}-, \mathrm{Y}-$, and $\mathrm{Gd}$-added alloys than $\mathrm{Co}-$ and $\mathrm{Ni}$-added alloys.

\section{Acknowledgement}

A part of this work was supported by BILAT project of Norwegian Research Council. Authors thank Mr. J. Nakamura, University of Toyama for his help of BOP calculation.

\section{REFERENCES}

1) S. Terai and Y. Baba: J. Jpn. Inst. Light Metals 13 (1963) 336-350 (in Japanese).

2) K. Matsuda, K. Kido, S. Taniguchi, Y. Uetani and S. Ikeno: J. Jpn. Inst. Light Metals 52 (2002) 398-402 (in Japanese).

3) D. E. Laughlin and W. F. Miao: Automotive Alloy II, (1998) p. 63.

4) A. Raman and H. Steinfink: Inorg. Chem. 6 (1967) 1789-1791.

5) R. Nesper, H. G. von Schnering and J. Curda: Z. Natur. 37 (1982) 1514-1517.

6) I. S. Dubeno, A. A. Evdokimov and Y. N. Titov: Russ. J. Inor. Chem. 30 (1985) 1707-1708.

7) A. Raman: Naturwissenschaften 54 (1967) 560.

8) A. A. Muraveva, O. S. Zarechnyuk and E. I. Gladyshevskii: Inor. Mater. 7 (1971) 34-36.

9) B. Chalmers (ed.): Progress in materials science, (Pergamon press, Oxford, 1963) Vol. 10, pp. 300-333.

10) K. Matsuda, H. Gamada, K. Fujii, Y. Yoshida, T. Sato, A. Kamio and S. Ikeno: J. Jpn. Inst. Light Met. 47 (1997) 493-499 (in Japanese).

11) K. Matsuda, T. Naoi, K. Fujii, Y. Uetani, T. Sato, A. Kamio and S. Ikeno: Mater. Sci. Eng. A 262 (1999) 232-237.

12) K. Matsuda, S. Tada and S. Ikeno: J. Electron Microsc. 42 (1993) 1-4.

13) K. Matsuda, S. Ikeno and S. Tada: J. Jpn. Inst. Metals 57 (1993) 11071113 (in Japanese).

14) K. Matsuda, H. Gamada, K. Fujii, Y. Uetani, T. Sato, A. Kamio and S. Ikeno: Metall. Mater. Trans. A 29 (1998) 1161-1167.

15) S. Ikeno, H. Matsui, K. Matsuda, K. Terayama and Y. Uetani: J. Jpn. Inst. Metals 65 (2001) 404-408.

16) G. Cliff and G. W. Lorimer: J. Microsc. 103 (1975) 203-207.

17) N. V. German, V. E. Zavodnik, T. I. Yanson and O. S. Zarechnyuk: Soviet Physics-Crystallography 34 (1989) 439-220.

18) P. K. Panday and K. Schubert: J. Less-common Metals 18 (1969) 175202.

19) N. V. German, V. K. Belskii, T. I. Yanson and O. S. Zarechnyuk: Soviet Physics-Crystallography 34 (1989) 437-438.

20) R. N. Corby and P. J. Black: Acta Cryst. B 33 (1977) 3468-3475.

21) S. J. Cowdery and F. X. Kayser: Mater. Phas. Bull. 14 (1979) 91-99.

22) S. Onurlu and A. Tekin: J. Mater. Sci. 29 (1994) 1652-1655.

23) L. G. Hou, H. Cui, Y. H. Cai and J. S. Zhang: Mater. Sci. Eng. A 527 (2009) 85-92.

24) M. H. Mulazimoglu, A. Zaluska, J. E. Gruzleski and F. Paray: Metall. Mater. Trans. A 27 (1996) 929-936.

25) P. Villars and L. D. Calvert: Pearson's Handbook of Crystallographic Data for Internetallic Phases, (American Society for Metals, Metals Park, Ohio, 1991).

26) C. Brukl, H. Nowotny and F. Benesovsky: Monatsh. Chem. 92 (1961) 967-980.

27) A. Raman and K. Schubert: Z. Metallkd. 55 (1964) 798-804.

28) K. Robinson: Acta Cryst. 6 (1953) 854-859.

29) F. Weitzer, H. Chen, Y. Du and J. C. Schuster: Intermetallics 14 (2006) 224-226.

30) A. Raman and K. Schubert: Z. Metallkd. 56 (1965) 44-52.

31) M. I. Gasik and O. I. Polyakov: Russ. Metall. 4 (1982) 177-185.

32) M. Cooper and K. Robinson: Acta Cryst. 20 (1966) 614-617.

33) J. B. Kusma and H. Nowotny: Monatsh. Chem. 95 (1964) 1266-1271.

34) W. Eidhed, H. Tezuka and T. Sato: J. Mater. Sci. Technol. 24 (2008) 21-24.

35) W. Eidhed, C. Limmaneevichitr, H. Tezuka and T. Sato: Mater. Sci. Forum 519-521 (2006) 377-382.

36) N. A. Belov, D. G. Eskin and A. A. Aksenov: Multicomponent Phase Diagrams: Applications for Commercial Aluminum Alloys, (2005) pp. 12-15.

37) H. Adachi, Y. Owada, I. Tanaka, H. Nakamatsu and M. Mizuno: Introduction to $\mathrm{DV}-\mathrm{Xa}$ method (in Japanese), 3rd ed. Tokyo, (Sankyo Shuppan Co., Ltd; 2001). 